\title{
自律神経失調症の臨床的および機能的研究
}

\author{
東邦大学医学部阿部内科教室（指視阿部涬夫教授） \\ 安部井瑠美子
}

\section{CLINICAL AND FUNCTIONAL STUDIES ON THE VEGETATIVE DYSTONIA}

\section{Rumiko ABEI}

The Second Clinic of Medicine, School of Medicine, Tōhō University, Tokyo

(Prof.: Tatsuo Abe)

\begin{abstract}
概要 不定な幾多の愁訴老有し，一般の内科学的検查定行小つても，特別の器質的疾患の見出され ない患者の中心は，自律神経失調症がかなり含まれているものと考元，乙れらの患者の躁床像や種

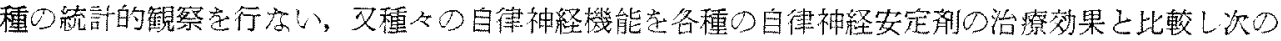

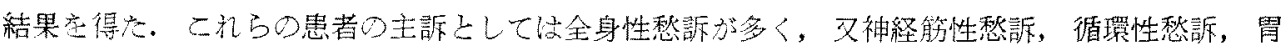

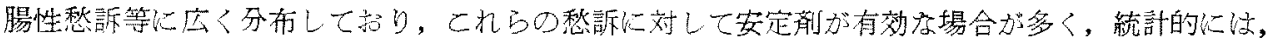

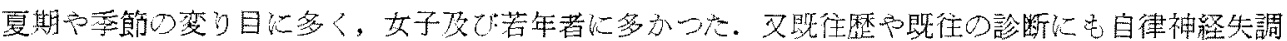

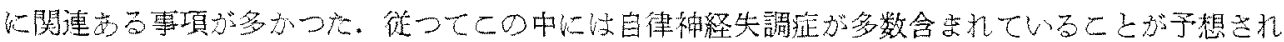

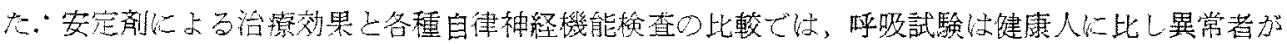

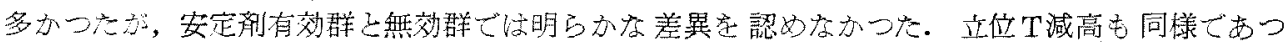

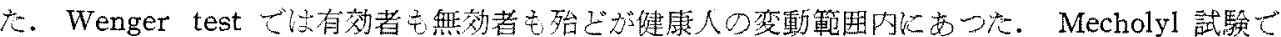

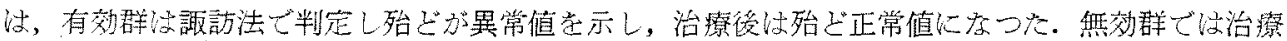

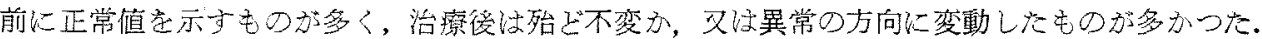

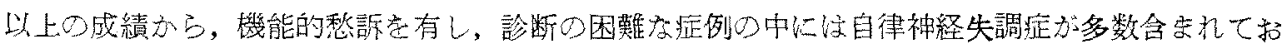
り，治療成績及び各種の娭査成績からこの過半数が自律神経失調であることを知つた。
\end{abstract}

\section{緒 言}

自律神経系江生体の植物性規制において，内分 泌系と共に一つの重要な調節機構であるが，その 調節機序に関しては，古くから幾多の業績があつ て, 解剖学的に者, 生理学的ないしは染理学的に も，加なり詳細に亘つて研究されている。これらの 研究の進歩と相诶つて，自律神経采の生体におけ る総括的な役割も，古来常に関心のまととされて おり，全身的な自律神経系の緊張買常が，㐫る種 の病態の主要因子であるとする立場方多くの学者 によつてとられて来た。すなわち1876年 Rosenbach は迷走神経の緊張異常によつて成立する迷
走神経症 (Neurose des Vagus) を詇じたが, 更に Noorden，Zuielzer 等, 同じような立場を 認める学者が続出している1)。1910年 Eppinger und Hess は，自律神経毒に対する個体の反応

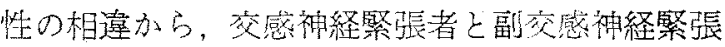
者に分類することを提袒した，後に二の分数は Bergmann, Siebeck, Wichmann 等の批制をう けたが，多くの批制や修正はあつても，根本的 にこのような立場を否定するものは少ない，今 日この上うな病態を自律神経失調症（vegetative Dystonie) と办, 自律神経不安定症 (vegetative Labilität）と噃んでいる。 
古来我が国には䟝気が極めて多かつたために， この対策に㸚し多大の成果のあげられている今日 においても，な扔軽症脚気と考えられがちな症例 が多いしかもこれらは最近の白米食の流行か ら，ますます增加の傾向にあることが整告されて いる、しかしながらこれらの症例を精密に検討す ると必ずしも脚気价かではなく，別の要因によ る病態上孝えざるを得ない毛のがかなり多い，阿 部教授 ${ }^{23) 4)}$ 数年に亘る調查加ら，この中心は明 ら加に他疾患の軽症と考えられるものの他に，脚 気に寻文他疾患にも属さない症例がかなり存在し ていることを指摘しこれらを脚気様状態と呼 んだ。このものの成因に関しては種々の憶測はあ るが，阿部教授はこれらの成因が多因子的であ つて, 広人内分泌系又山自律神経系の異常にも求 めねばならないことを主張している，安部井5 は、これらの患者を精密に稌討し，その中に脚 気もあるが，なお自律神経失調症ともいうべき病 態が26.4\%に認められたことを報告した。そこで 私は, 各種不定の愁訴を有し, 理学的に殆ど所見 がなく，しかも各種の臨床检查にも拘らず診断が 困難で，治療し難い症例の中に汢（いわゆる脚気 様状態もこの中に含まれるが），自律神経失調症が かなり含まれているものと考え，これらを便宜上 「対象」と名づ， その臨床像，検查所見及び各 種自律神経機能を㮥討し，いささか所見を得たの でっこ〉に報告守る。

\section{検查対象及び方法}

昭和34年 1 月加ら12月迄に東邦大学阿部内科を 訪れた外来初壃患者の中, 自律神経性愁訴として 最も起こり易い全身性愁訴（全身怢急感，易疲学 性, 体重娍少, 微熱, 盗汗), 神経筇性愁訴 (下䁌 㑢怠感，不眠，めまい，しびれ感，雇こり，背 痛, 腰痛, 頭重, 頭痛), 偱嘼性愁訴 ( 轺促迫, 脑内苦悶, 浮腫), 胃晹性愁訴（食欲不 振，胃痛，惡心，呕吐，腹部不快感，腹痛，便 秘，下峲）を主訴々する患者1198例を主訴别に分

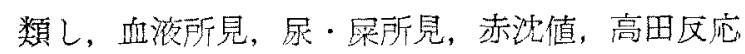
その他の阶機能検查，胸部X線写真，梌烣，胃液
検查, 十二指腸液検查, 胃及び胆のう透視, 心電 図，基礎代謝率，PBI，I131 摂取率，血清蛋白量 およびその分屑像, 血清コレステロールおよびア ルカリフォスファターゼ, 血清ムコ蛋白等を適宜 参考として，可及的に他疾患を除外し，残りの 135例在対象（以下対象）とした。 又昭和 34 年 1 月から12月汽に阿部内科に入院した同様の患者, 又は他の疾患で入院して，その疾患の経過とは無 関係に消長する種々の自律神経失調性愁挀を有し た患者18例当対象 (以下入院対象)とした。

上記対象の主訴别分布，日别・年命别・性别分 布, 航往柇及び現病に対する関連事項の有無, 現 病に対する既往の診断，他党定状をしらへ各種薬 物の治療效果を愁訴及び症状の消長から刵定して 検討した。

上記対象及び昭和35年1月から10月迄に阿部内 科外来を訪れた対象と同様の患者の一部合計67例 に自律神経機能検查を実施し, 各检査法と治療経 過と老比較し，又各検查法相互の関係をしらべ た。

梌查法は下記のものを選んだ。

1. 呼吸試験。福田無水式呼吸計を用い，空腹 安静時の乎吸曲線を $5 \sim 7$ 分描写し, その直徭呼 吸をできるだけ停止せしめ，更に数十回過呼吸を 行なわせた後再び呼吸をできるだけ停止せしめ， それそれの停止時間 $\mathrm{A}$ 及びB（秒）を測定した。 呼吸停止は吸気㭙に行なわせた。

2. 立位心電图T減高。卧位及び立位で心電図 をとり，標準第 2 肢䇋薄において，卧位T一立位 $\mathrm{T}(\mathrm{mV})$ をつてTの減高を表的し，安部井5) に徒いT窚高0.12mV 以上異常減高とした。

3. Wenger-油中心自律神経緊張状態測定法. 安部井5)の行なつた健康人100人の成績を基にし て，昭和34年9月を中心に 6 月加ら12月の間に測 定し，室温および年令による補正，測定時間等の 条件を一致せしめ，同一器具を用い同一の方法で 測定し算定した。

4. Mecholyl 試験. 体重 $60 \mathrm{~kg}$ 当り 10mgの $\beta$ methyl-choline chloride 筋注し，注射前及び 
注射後 25 分迄の血王更び服指数を，注射直後の 5 分間は30秒毎に，その谽は 1 分每に測定した。 最高血任の推移明線を，縱軸は血代 $5 \mathrm{mmHg}=$ $10 \mathrm{~mm}$ ，横軸注 1 分間 $=10 \mathrm{~mm}$ の直交軸上㳊描き，二 の曲線から Gellhorn の方法6)，冲中法7) 及び䚺 訪法8）の3方法によつて，個体の交感神経中权の 興偣性を判定し比較した。橫軸は注射前の最高血 压を0として定めた。Gellhorn 法は横軸と血圧 曲緗のかこむ面積を，頭軸より上は十，横軸より 下は一とし，その代数和で求めた。+6.45以上 をI 型 (sympathetic hyperreactor), +6.39 -35.48 II 型 (intermediate group), -35.54 以上を开型（sympathetic hyporeactor）と制定 した。冲中法は下降した血圧が10分前後で基線に 復し、さらに $10 \mathrm{~mm} \mathrm{mg}$ 以上上昇するもの利型，曲 線が20分以内に基線に復さないものを $\mathrm{P}$ 型と制定 した，又諏訪法は，血在曲線つ最下降点妾通り基 線に平行な直線，血圧曲線及び25分の点で基線と 直交する面缐のかこむ面積 $\left(\mathrm{cm}^{2}\right)$ を血代の最大 偏差で除した值をもつて判定指標とした。

5. noradrenalin 試験. Nerson \& Gellhorn 法6)に準じ， noradrenalin $0.04 \mathrm{mg}$ を60秒間に静

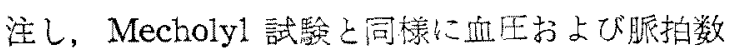
を測定し，最大血王の最大变影を脈拍の最大変 動によつて除した值 parasympathetic index

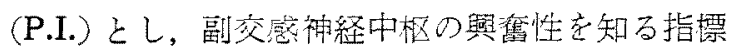
(P.I. 值の低い程與鹤性大) とした。

\section{検查成績}

1. 呼吸試騃異常の吟味

健康人15例及び自律神経安定剂 bellergal の有 効であつた症例16例（治療前）につき，呼吸試驗

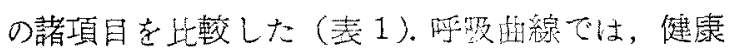
人に不整は 1 例もなく， bellergal 有効例では16 例中15例 $(93.8 \%)$ に不整を認的た。呼吸停止時 間Aでは健康人は22秒加ら110秒の变動を示し, 平均值注43.9土24.7秒であった， bellergal 有效 例では 0 秒〜 92秒の変動を示し, 平均值住25.3土 21.6 秒で，健康人に比し $0.05>\mathrm{P}>0.02$ で有意 の差を示した。 $\mathrm{B} \leqq \mathrm{A}$ 注健康人に注認められず,

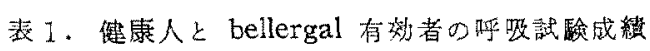

\begin{tabular}{|c|c|c|}
\hline & $\underset{15 \text { 例 }}{\text { 健 }}$ & $\begin{array}{c}\text { B剂有效者 } \\
\qquad 6 \text { 例 }\end{array}$ \\
\hline 曲線不整 & 0 & $\begin{array}{l}15 \\
(93.8 \%)\end{array}$ \\
\hline $\begin{array}{c}\text { A 变動 } \\
\text { (利) 平均 }\end{array}$ & $\begin{array}{c}22 \sim 1 / 0 \\
43.9 \pm 24.7\end{array}$ & $\begin{array}{c}0-92 \\
25.3 \pm 21.6^{1)}\end{array}$ \\
\hline $\begin{array}{c}B \text { 变動 } \\
\text { (秒)更均 }\end{array}$ & $\begin{array}{c}30 \sim 170 \\
68.6 \pm 41.8\end{array}$ & $\begin{array}{c}0-85 \\
29.7 \pm 23.9^{2)}\end{array}$ \\
\hline $\begin{aligned} & \text { 变動 } \\
B-A & \text { 亚均 } \\
& \leqq 0\end{aligned}$ & $\begin{array}{c}+1 \sim+8 \\
+24.7 \pm 23.9 \\
0\end{array}$ & $\begin{array}{c}-13 \sim+32 \\
+1.3 \pm 10.7^{3)} \\
9 \\
(56.3 \%)\end{array}$ \\
\hline & & $\begin{array}{l}0.05 \\
0<0.07\end{array}$ \\
\hline
\end{tabular}

bellergal 有效者では9例 $(56.3 \%) に$ 認的られ た。以上の結果に基つき呼吸曲線の不整，Aの短

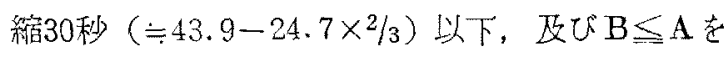
異常とし,この三者の出現の数により異常度を 一, +. H, H已区別した。

2. Mecholy1 試験制定の吟味

Mecholyl 試騒の制定法前述の三法につき比 較㭘討するために，刘象36例の bellergal 又流 esanine 等の自律神経安定剂(以下安定剂)によ る治療前後の Mecholyl 試騃成績を三法で算出 し，これらを洁療後の臨床的経過と比較した。臨 林的経過は愁訴及び理学的所見の推移によつて㭘 討した。すなわち图1の如くGellhorn法を用い た場合には治療前值は安定剂の有効であつたもの も無効であつたものも特别の差異を見出すこには

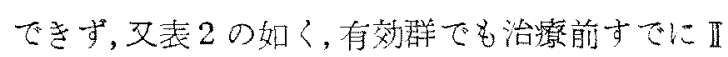

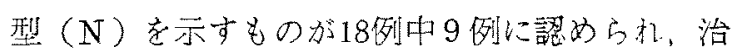

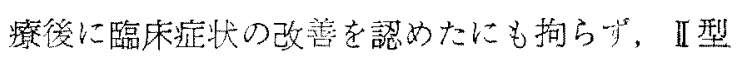

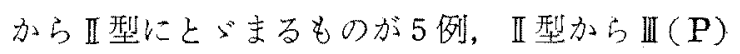

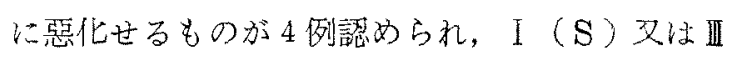
から正に好転せるもの法了例にすぎなかった，又

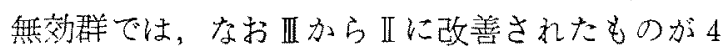
例認められた。冲中法に上る制定でも㱠ど同様の 


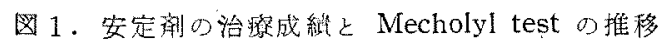
(Gellhorn 法)

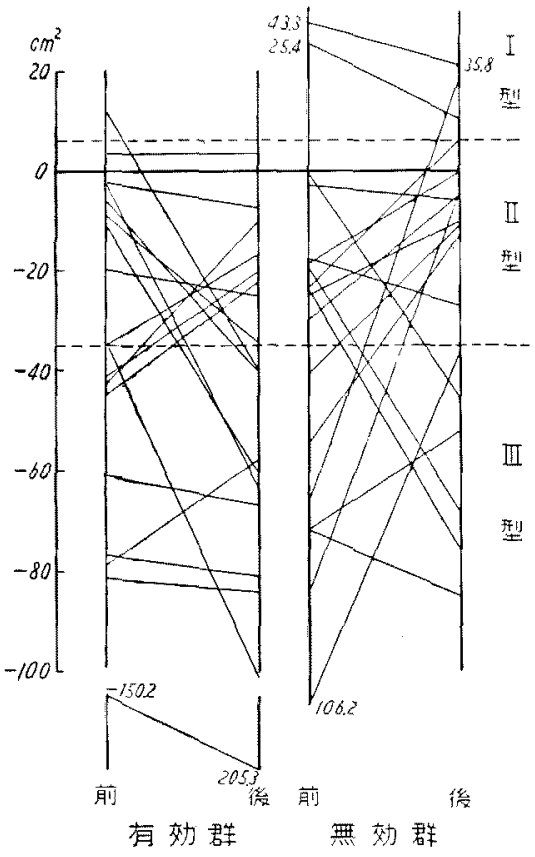

表 2. Mecholyl testに的计る三判定法の比敬

\begin{tabular}{|c|c|c|c|c|c|c|}
\hline & $G$ - 法 & 効 & 群 & $G$ - 法 & $\begin{array}{c}\text { 奻 } \\
\text { 冲中法 }\end{array}$ & $\begin{array}{l}\text { 群 } \\
\text { 諏訪法 }\end{array}$ \\
\hline & $\begin{array}{l}0 \\
0 \\
1\end{array}$ & $\begin{array}{l}0 \\
3 \\
1\end{array}$ & $\begin{array}{l}1 \\
9 \\
0\end{array}$ & $\begin{array}{l}2 \\
0 \\
0\end{array}$ & $\begin{array}{l}2 \\
0 \\
0\end{array}$ & $\begin{array}{l}5 \\
0 \\
0\end{array}$ \\
\hline$N$ & $\begin{array}{l}0 \\
5 \\
4\end{array}$ & $\begin{array}{l}1 \\
4 \\
2\end{array}$ & $\begin{array}{l}1 \\
0 \\
0\end{array}$ & $\begin{array}{l}2 \\
4 \\
4\end{array}$ & $\begin{array}{l}1 \\
5 \\
4\end{array}$ & $\begin{array}{l}2 \\
7 \\
2\end{array}$ \\
\hline$\rho Z_{P}^{S}$ & $\begin{array}{l}0 \\
3 \\
5\end{array}$ & $\begin{array}{l}0 \\
2 \\
5\end{array}$ & $\begin{array}{l}0 \\
? \\
0\end{array}$ & $\begin{array}{l}1 \\
4 \\
2\end{array}$ & $\begin{array}{l}1 \\
3 \\
2\end{array}$ & $\begin{array}{l}0 \\
0 \\
2\end{array}$ \\
\hline
\end{tabular}

結果となつた（表2）。これに比し諏訪法によれ ば，図20如く安定剤有效群では，治療前3.76 2.09の間にあつたものは18例中 1 例のみで，他の 17例中10例は3.76以上の高值を，7例は2.09以下 の低值を示し，しかも治療後は，二の17例中16例 は3.76〜2.09の間に推移した。すなわち，3.76〜 2.09 intermediate group $(\mathrm{N})$, 3.76以上索 sympathetic hyperreactor (S), 2.09以下を sympathetic hyporeactor (P) とすれば，この 成續は18例中 2 例学除いて臨床的推移已極めてよ く一致している。一方安定剂無効群では18例中 5

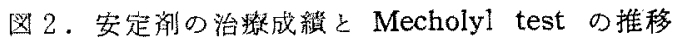
(骤訪法)

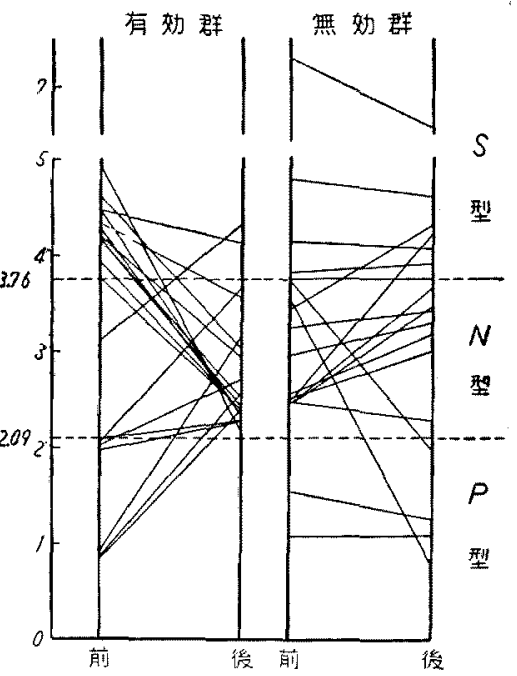

例は治療前 Sで，治療後もSにとぶまり，2 例は 治療前後でPからPにとふまつていた。 又11例は 治療前既に $\mathrm{N}$ と制定され，このうち治療後なお $\mathrm{N}$ にとどまるもの7例，S文はPに惡化するものそ れぞ机2例が認められた。すなわちこの場合に も，安定剤の臨床的影響とよく一致した成績を示 している。

以上の結果から，Mecholyl 試騃の制定には諏

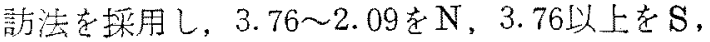
2.09以下を $\mathrm{P}$ と制定することとした。

3. 外来患者の主訴刟分類

前述の自律神経失調性愁訴を主訴として来院し た患者は，昭和34年 1 月から 12 月迄の外来初診患 者総数 4087 名中1198名（29.3\%）であつた。これ らの患者の主訴別，疾患別分布は表 3 の如く，何 らかの確実な診断が得られたものは1063例（88.7 $\%$ であつた。残余の 135 例 $(11.3 \%)$ を前远の 如く対象とした（表中 No. 9).

4. 対象の月别・年令別・性別分布及び臨床像 前項に見出された対象 135例の月别，性别，年 令别分布は表 4 の如くであつた。 月别には7 月 に，同月の来院患者総数の $6.4 \%$ と最多く，9 月，4月等の季節の变り目にもそれぞれ $4.6 \%$, 
表 3．外来患者の主挀別分類（昭和34年）

\begin{tabular}{|c|c|c|c|c|}
\hline & 全身性愁核 & 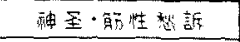 & 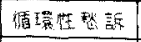 & 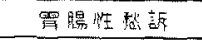 \\
\hline 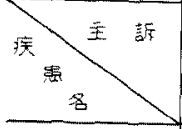 & 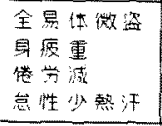 & 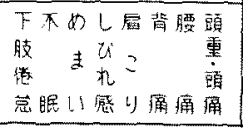 & 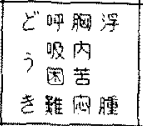 & 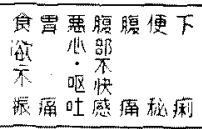 \\
\hline 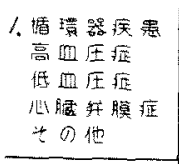 & $\begin{array}{l}41 \\
1,1\end{array}$ & $\begin{array}{r}135532314 \\
1 \quad 2 \\
1 \quad 72 \\
\end{array}$ & 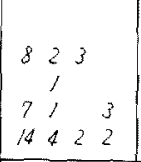 & 1 \\
\hline 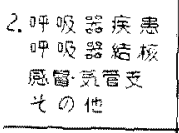 & $\begin{array}{rrrrr}8 & & 1 & 7 & 1 \\
13 & 3 & 1 & 28 & 8 \\
3 & 2 & 7 & 2 \\
\end{array}$ & $\begin{array}{rrrr} & 1 & 7 & 1 \\
3 & 1 & 512 & 21 \\
3 & 11 & 1 \\
\end{array}$ & $\begin{array}{l}218 \\
113 \\
2517 \\
\end{array}$ & $\begin{array}{lll}2 & & 1 \\
1 & 2 \\
\end{array}$ \\
\hline 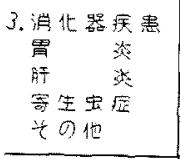 & $\begin{array}{l}8 \\
11,1 \\
42 \quad 2 \\
\end{array}$ & $1^{2}$ & , & 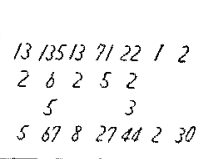 \\
\hline 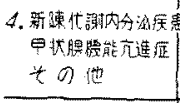 & 111 & I & $\begin{array}{l}81 \\
3 \\
\end{array}$ & 1 \\
\hline 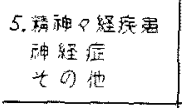 & $\begin{array}{l}3 \\
2\end{array}$ & $\begin{array}{l}1 \\
316\end{array}$ & $1 / 10$ & 11 \\
\hline 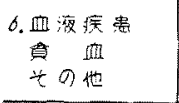 & 311 & $17 / 21$ & 81 & 15 \\
\hline 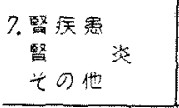 & $?$ & 1 & 12 & 17 \\
\hline $\begin{array}{l}\text { 8.云の他の } \\
\text { 疾 } \\
\end{array}$ & 12 & 41582121010 & $2+52$ & 1535 \\
\hline $\begin{array}{l}9 . \text { 研㠰对商 } \\
\text { 合㖕 }(\%)\end{array}$ & $\begin{array}{l}286 \quad 1 \\
33(24.490)\end{array}$ & $\begin{array}{c}112 ? / 53 / 10 \\
40(29.6 \%)\end{array}$ & 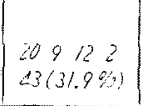 & $\begin{array}{r}44343 \\
19(14.1 \%)\end{array}$ \\
\hline
\end{tabular}

$4.2 \%$ と多くなつている。12月方 2 月の冬期に

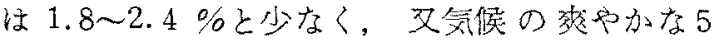
月にも $2.2 \%$ と少ない。性别では男子58例(42.0 \%)に対し，女子注77例 $(57.0 \%)$ 乙や小多、傾 向が見られた。年命的には21子から30才汽が47例 $(34.8 \%)$ と最高を示し，41才以上のものは的ず か21例 $(15.6 \%)$ であつた。

主訴别分類は歨 3 の如くで，全身性愁訴が33例 $(24.4 \%)$ ，神経性愁訴が40例 (29.6\%), 循環性愁 訴が43例 $(31.9 \%)$ で残りの19例 $(14.1 \%)$ が胃 晹性愁訴となつている.

轭往歷中特に現病歴に関係深いものを取上げて 見ると表 5 の如く，自律神経に関連の深い髮称疹
の㷺往や，過学，夏期疲労，各種将患の経過等， 肉体的悬荷や季節的頶荷が目だつている。現病に 刘し来院前に受行た診断及び当内科外来で一応つ

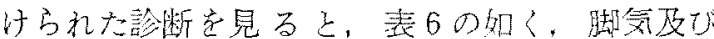
これに類した䛦断が多く，又自律神経の関与の强 いと思われる各種病名をつけられたものが多かつ た。

他賞的所兒は表7 の如く，無所見のものが 135 例中93例 $(68.8 \%$ ) で，他の42例以は軽度の機能 的所見が認められたのみであつた。治滰成績では 表 8 の如く，脚気と考えられてどタミン $\mathrm{B}_{1}$ 郕を

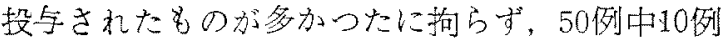
(20\%) にのみ有效で，他の40例 $(80 \%)$ には無 


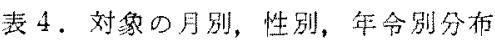
月别性别分布

\begin{tabular}{|c|c|c|c|c|c|}
\hline \multirow{2}{*}{ 月 } & \multirow{2}{*}{ 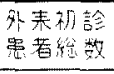 } & \multicolumn{2}{|c|}{$x_{1}$} & 3 & \multirow[b]{2}{*}{$\%$} \\
\hline & & 3 & 우 & 計 & \\
\hline l & 396 & 2 & 5 & 7 & 1.8 \\
\hline 2 & 345 & 2 & $b$ & 8 & 2.3 \\
\hline 3 & 353 & 3 & 7 & 10 & 2.8 \\
\hline 4 & 376 & 10 & 6 & 16 & 4.2 \\
\hline 5 & $3 / 8$ & 2 & 5 & 7 & 2.2 \\
\hline 6 & 374 & 6 & 6 & 12 & 3.2 \\
\hline 7 & 312 & 8 & 12 & 20 & 6.4 \\
\hline 8 & 310 & 4 & 3 & 10 & 3.1 \\
\hline 9 & 343 & 9 & 7 & 16 & 4.6 \\
\hline 10 & 342 & 0 & 6 & 12 & 3.5 \\
\hline 11 & 246 & 3 & 5 & 8 & 3.2 \\
\hline 12 & 366 & 3 & $\theta$ & 9 & 2.4 \\
\hline 棓 & 4087 & 58 & 97 & 135 & 3.3 \\
\hline
\end{tabular}

年令别今布

\begin{tabular}{c|c|c|c|c|c}
\hline $20 \pi$ 以下 & $21-307$ & $3 / 20$ 4 & $4-507$ & $5 /-60 \lambda$ & 61 才以上 \\
\hline 29 & 47 & 38 & 15 & 4 & 2 \\
\hline
\end{tabular}

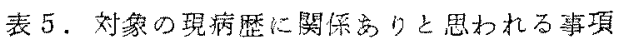

\begin{tabular}{|c|c|c|c|c|c|}
\hline 爰 & 麻 & 疹 & 5 & 栖畫 & 1 \\
\hline 過 & & 学 & 5 & 屈折障害 & r \\
\hline 娃 & & 娠 & 4 & 畕 & 1 \\
\hline 䨓 & 期疲。 & 労 & 4 & 胆のう摘出 & 1 \\
\hline 入. & 工流 & 痤 & 3 & 肪骨周囲膿曒 & 1 \\
\hline 脚 & & 文 & 3 & 甲状腺切除 & 1 \\
\hline 霄 & 下 & 垂 & 2 & 盢切除 & 1 \\
\hline 脑 & 結 & 核 & 2 & 卵褁摘出 & 1 \\
\hline 感 & & 䍖 & 2 & 塽地症 & I \\
\hline 虫 & 㘮 & 除 & 2 & 言血圧 & l \\
\hline 分 & & 㚾 & 2 & 鈇椎畸型 & 1 \\
\hline 肋 & 㯰 & 次 & 1 & ゆ着泩䯕膘次 & l \\
\hline$\phi$ & 耳 & 次 & $l$ & 脑部買通鋶則 & I \\
\hline
\end{tabular}

表 6。対象に対する慣用猃断

\begin{tabular}{|c|c|c|c|}
\hline \multicolumn{2}{|c|}{ 的往 の猃断 } & \multicolumn{2}{|l|}{ 阿部内科心おりる診断 } \\
\hline 脚文 & $b$ & 脚気、及び脚気梾状熊了 & 35 \\
\hline 心灆神経症 & 4 & 似蕰神経症 & 30 \\
\hline 器盾的心疾恕 & $b$ & 腮下垂 & 25 \\
\hline 自律神経失蔨症。 & 3 & 学羿性便私 & 16 \\
\hline 更年期障昰 & 2 & 雷つトニ- & 13 \\
\hline 胃アトニ-・胃下垂 & 4 & 更年期障害 & 8 \\
\hline 神経症 & 4 & 䡒神経症 & 4 \\
\hline 肝 炎 & 2 & 晹下垂 & 3 \\
\hline 头の他 & 8 & 本態性高体温症 & I \\
\hline
\end{tabular}

淩 7. 对像に認められた他覚的所見

\begin{tabular}{|c|c|c|c|}
\hline 策器怟下 & 5 & 鼠大直生 140 以上 & 7 \\
\hline 拆の翼常 & 0 & " " 90以下 & I \\
\hline 心雑 晋 & 0 & 腓晹筇铚瘁 & 8 \\
\hline 第 2 䏦動脈音穴進 & 8 & 腱反射兮進 & 6 \\
\hline 脈圧 $60 \mathrm{mmHg}$ 以上 & 9 & 減弱又は消失 & 5 \\
\hline 無症状 & 93 & & \\
\hline
\end{tabular}

表 8. 対象に投与された薬品とその效果

\begin{tabular}{l|c|c}
\hline 使用薬品 & 有 奻 & 無 \\
\hline Alinamin & 10 & 40 \\
Bellergal & 20 & 5 \\
Esanine & 0 & 1 \\
Carnigen & 0 & 2 \\
Atraxin & 0 & 1 \\
Astin & 0 & 1 \\
Harmonine & 0 & 0 \\
Ritalin & 1 & 1 \\
Noctan & 0 & 0 \\
Reserpine & 0 & 1 \\
Bromwasser & 3 & 9 \\
Luminal & 1 & 0 \\
\hline
\end{tabular}


表9. 入院対象の自他觉的所見

\begin{tabular}{|c|c|c|c|c|c|c|c|}
\hline A 8 & F & \begin{tabular}{|r|}
$x$ \\
$x$ \\
$x$
\end{tabular} & 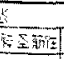 & 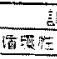 & E & 潶学的所兒 & 渚 \\
\hline 形O & jof & + & itt & + & H & $P_{2}$ 八措 & 梅雷 \\
\hline mo & $26 m$ & + & H & $H$ & tit & 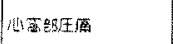 & \\
\hline 阅O & $27+$ & H & H & + & + & 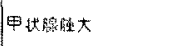 & 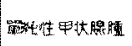 \\
\hline Ro & $2 \pi$ & + & $\#$ & + & H+ & 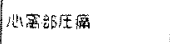 & \\
\hline 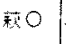 & 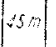 & + & + & H & + & 售血纴 & 低四玨撞 \\
\hline 米O & iff & + & $+\cdots$ & - & + & 要徏 & \\
\hline 電。 & $\omega t$ & + & H & + & H & FSRTR & 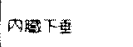 \\
\hline 漂 & 19.7 & + & + & - & H & & \\
\hline 10 & $4 m$ & + & - & + & - & & \\
\hline 青○ & $34+1$ & + & + & H & H & $P=\bar{\Omega}$ 远 & \\
\hline No & $32 r$ & + & + & i+ & - & $2 \pi \pi$ 潐 & 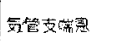 \\
\hline EO & $36 f$ & H & + & + & - & 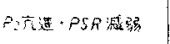 & 轮生症 \\
\hline 䛶0 & 27 & + & +4 & + & - & & \\
\hline \pm 0 & -44 & + & $\therefore$ & + & - & & 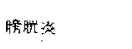 \\
\hline 柴O & 1000 & - & $\div$ & + & - & 㽙浩深 & 化空至明外收的 \\
\hline 広O & $20+$ & - & $\because+$ & 4 & \# & 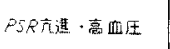 & 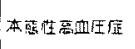 \\
\hline NO & 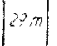 & - & $\div$ & - & H & 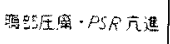 & \\
\hline 由0 & $39 n$ & - & + & \# & - & & \\
\hline
\end{tabular}

表10. 安定用治燎後に対与る入院対象の愁訴の推移

\begin{tabular}{|c|c|c|c|c|c|c|c|c|c|}
\hline \multirow{2}{*}{ 日名 } & \multirow{2}{*}{ 年徍 } & \multicolumn{4}{|c|}{ 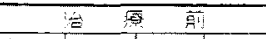 } & \multicolumn{4}{|c|}{ 治 療 位 } \\
\hline & & 全夏空 & 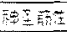 & 需謤学 & 湮性 & 全等 & 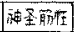 & 活環性 & 雷胆陮 \\
\hline 武O & $60 t$ & + & H & + & + & - & + & - & - \\
\hline 風 0 & $26 \mathrm{~m}$ & + & t+ & 㘫 & 匆- & - & - & - & - \\
\hline 成：０ & $27 f$ & H & + & + & + & + & \# & + & + \\
\hline ×0 & $20 \%$ & + & \# & + & +4 & - & - & - & + \\
\hline 萩O & $45 \mathrm{~m}$ & + & H & + & + & + & - & - & - \\
\hline 米O & $37 f$ & + & 册 & - & $\#$ & + & - & - & - \\
\hline 溥 0 & $4 i$ & + & H & + & H & - & - & - & - \\
\hline 晹○ & $10 \%$ & + & H & - & $H$ & - & - & - & - \\
\hline 八O & 140 & + & - & + & - & - & - & - & - \\
\hline 素○ & 397 & + & + & + & H & - & - & - & - \\
\hline NO & 39 & + & + & $H$ & - & - & - & + & - \\
\hline 望O & 387 & $\because$ & + & + & - & + & + & + & - \\
\hline 衤琴O & $27 \pi$ & + & $i+1$ & + & - & + & + & - & - \\
\hline \pm 0 & $44 t$ & + & H & \# & - & - & - & - & - \\
\hline 柴O & $86 m$ & - & $H$ & H & - & - & + & - & - \\
\hline 広 & $50 \%$ & - & $4+4$ & $H$ & $H$ & - & + & - & - \\
\hline 110 & $29 \mathrm{~m}$ & - & + & - & +4 & + & + & - & - \\
\hline BO & $39 \mathrm{~m}$ & - & + & $\#$ & - & - & + & - & - \\
\hline
\end{tabular}

効であつた。これに反し， bellergal の有効であ つたものは25例中20例（80\%）であつた。

5. 入院対象の臨休像之自律神経安定用との関 係

自律得経安定剂の有効であつた入院坟象18例の 臨床像は, 表9の如くであつた。これらの患者に は同時に各種の疾费含併していたものが多い が，愁訴及び他覚症状沬，これらの疾患と平行せ ずに存在した。 bellergal 投与後の愁訴の消長は 表100如く，全例において同時に存在した各種疾 患の消辰とは無関係に, 愁訴及び症状の軽減もし くは消失が見られた。

6. 対象の臨床的経過上自律神経機能

上記の対象の一部及び昭和35年 1 月から10月迄 に当内科外来を訪れた患者，又汁入院した患者の うち，対象と同椂にして選んたものの一部合計67 について, 自律神経安定剤の治療効果をしらべて 有效群と無効群を区别し，治撚前及び治療徣の各 種自律神経機能蚞查成續を比較した。

\section{(1) 呼吸試験}

呼吸試戨と治療成績を比較できたものは59例で あつた。そのうち32例は安定剂によつて治癒し， 27例は無效であつた。この雨群の治療前における 乎吸試験の成續主表11の如くであつた。すなわ 各項目で有効群は無效群に比し異常所見の出現率 が高く，Aの平均值は無效群で健康人平均と注” 一致し，有效例と健康人との間には有意の差を示

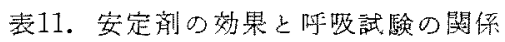

\begin{tabular}{c|c|c}
\hline & 有効群 32例 & 無谇群 27例 \\
\hline 曲線不整 & $28(87.5 \%)$ & $15(55.6 \%)$ \\
$A 30$ 秋以下 & $19(59.4 \%)$ & $10(37.0 \%)$ \\
$A$ 平均値 & $30.7 \pm 24.7$ & $40.3 \pm 28.8$ \\
$B \leqq A$ & $11(34.4 \%)$ & $11(40.7 \%)$ \\
\hline$H+$ & $9(28.1 \%)$ & $3(11.1 \%)$ \\
+ & $12(37.5 \%)$ & $8(29.6 \%)$ \\
+ & $3 i(96.9 \%)$ & $22(81.4 \%)$ \\
\hline
\end{tabular}


図3，安定剂の效果上立位T減高の比粼 有㤸群

無 效群

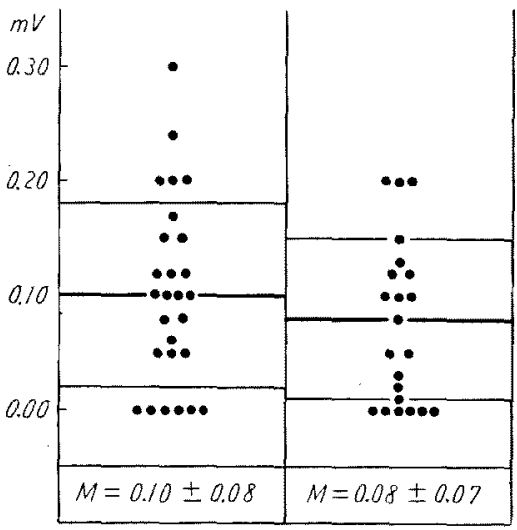

図4。愁訴々立位T減高の関俰

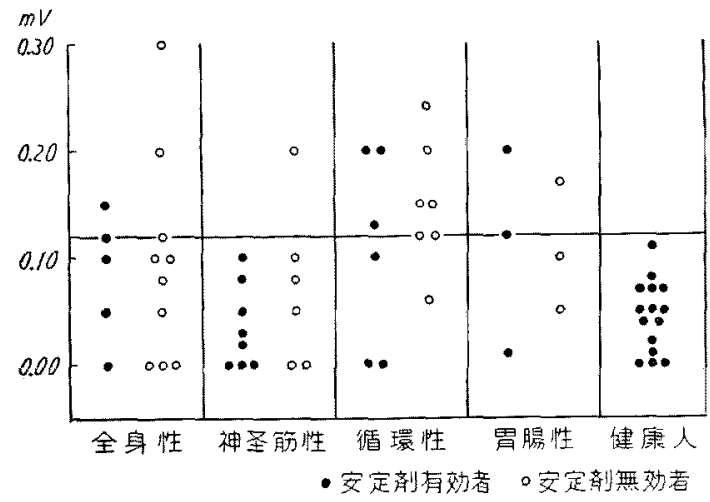

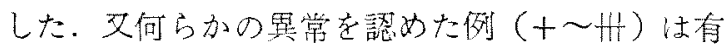
效例て32例中31例（96.9\%）であつたが，器频例 て舟27列中22侈 $(81.4 \%)$ に認的的た。

(2) 立位心雮园T源亳

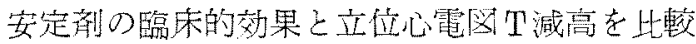
し得な例は49例で，その中有效群は27例，無効群

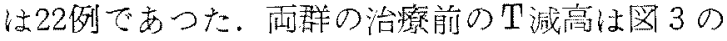
如くで，平均值奻有效群0. $10 \pm 0.08 \mathrm{mV}$, 無効群

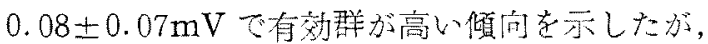

推計学的に有意心统な加つた。文 $0.12 \mathrm{mV}$ 以上

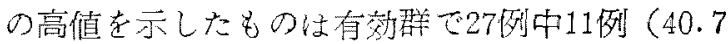
$\%$ ，無效群て22例吅7例 $(31.4 \%)$ で無效群が や>低辫であつた。

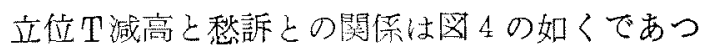

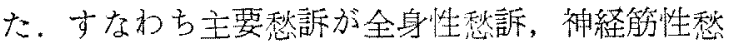

图 5. 安定用による治療乙Wenger test の推移

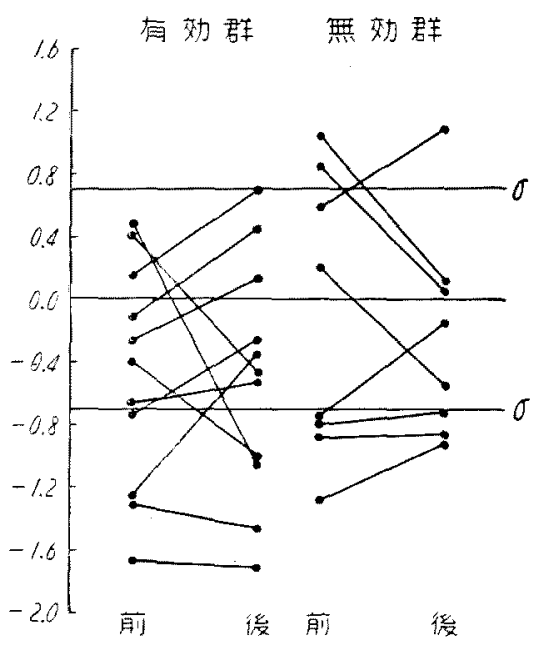

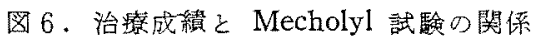
有效群 無効群

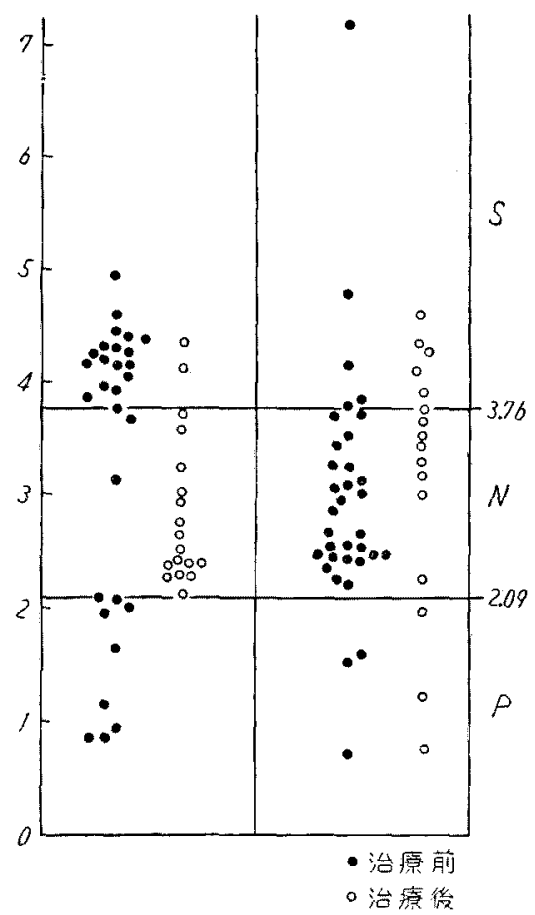

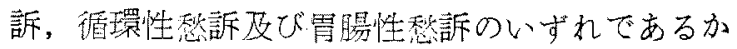
によって対象分類し, 各群のT異常減高の出現

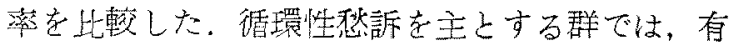

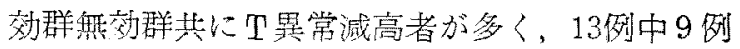

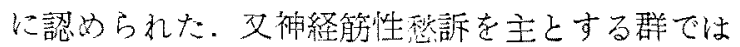


図 7. 治潦成纉上 P.I. 值
有効群
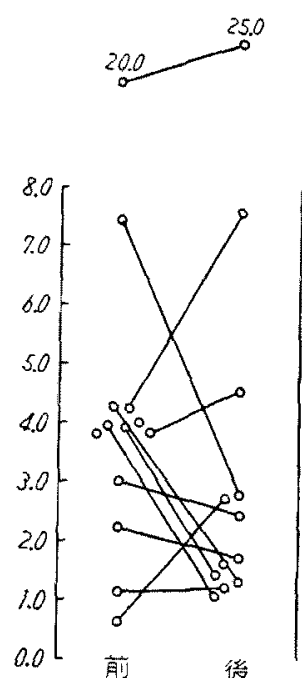

後
無効群

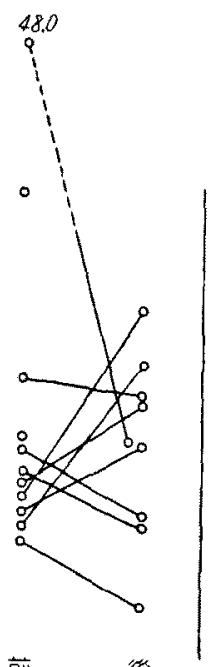

前後
異常は1例のみに認められた。

(3) Wenger-冲中法

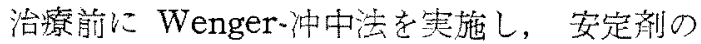
効果と比較し得た患者は19例で，その中有效は11 例，無効群は 8 例であつた。図 5 は両群の治療前 徯の比輍であるが，治療前有效群は無効群に比し 交感神経緊張側（負の側）により多く倾く傾向が 見られた。し名し治療欲の成績で性，両群共に一 定の傾问を示さなかつた。

(4) Mecholyl 試衯

治療前にMecholy1試唤を行なつて, 安定郕の

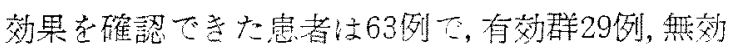
群34例であつた，图6 注治療前淩の雨群の比校で

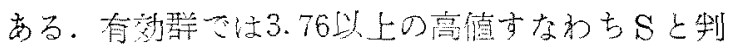
定されたものが18例（62.1\%)，2.09以下の低檤す

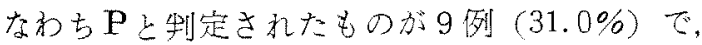

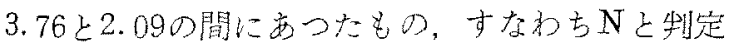
されたものは2例(6.9\%)に過ぎなかたすなる

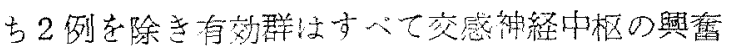
㤬に異常を示した。これに反し筫效群では34例中 26例 (76.5\%) はN型であり, S 型法5 例 (14.7 $\%), \mathbf{P}$ 型は3例 $(8.8 \%)$ にすきなかつた。

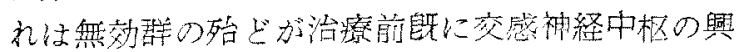

寶性が正常であることを物語つている．及治療後 の成續では，有効群は2 例を除きすべてNに推移 し，無効群ではNにとぐまるものの他に，Nから

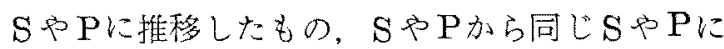
止まるもの、存在したことは既に述べた（四2）.

(5) noradrenalin 試験

治療前後て P.I. を比較し得たものは有效群13 例，槃勃群11例であつた。両群に括ける治療前の 比較及び治療㣪の推移は图7に示した。沿療前 値では両群の間に特別の差異を想めることはでき ず，及治療得においても一定の推移を認めること はできなかつた。

\section{考察}

白律神経失調症の存在は古来多くの学者によつ て指摘されて来たが，良来このものは自律神経系 の様相客锥的に適確に把提して論ぜられたもの ではない，㹶つて古来その定義や簕疇或は分類に 関しては種々議論の多いこころであるが，自律神

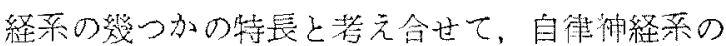
失調が主たる要因であると考えざるを得ないるう な病態像は，往来数多く指摘されているばかりで はなく，我及の身辺でもしばしば認め得るもので ある、

古来自律神経系の障害は，その支配領域のすべ ての䁍器の機能障害像として表現されるものと考 えられて来たが, 葴器の機能障害は自律神経系の 失調と特異的に結でっくものではないから，種々 の別の特長的事項索参考にする必要加㐫る。蓑な わち $\mathrm{Mark}^{1}$ ○指摘する如々，自倠神経采の與 憲は全神経系の広範索支配領域に同時に一溙に搪 多るから，本症の臨床像の第一の特長洁全身性愁 訴が存在することであるとされている。页，それ はその支配領域のあらゆる臟器の蟣能に影響を及 浔しているから，本症の症状は一定の藏器に㾫る \&のではなく，種々の異なつた系統の藏器の機能

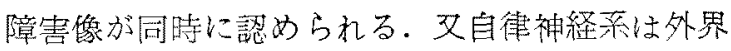
の刺激に対する homeostasis に不可久要素で 西るから，外界の微細な变化によつてこれらの機 能障害像江不安定に消長し易い，更に江自律神経 
系の解部学的位置加ら，それは精神々肉体の耐面 から強い影彎を受计易い。

自律神経失譟症の症状としては，Wichmann")， $\mathrm{Mark}^{11}$, Scholz10) 等の記載があるが，自律神経 失調症の把握には，この上うな症状の列举の他 に、二れらの症状群索上述の如き㩁点加ら分析す ることも重要であると思われる。

このような観点に立てば，本症の臨床像の把握 には，一般の内科学的症状の観察法と自ら異なつ た力法を明い极はならないことはもちろんである が，私取りあえず，内科学的に最も普遍的な診 断法のみによつて臨床像を観罝してみた。このよ うにして分類したものでも，表 3 に見るように 診断不確定のま〉残された 135 例の主訴別分類に も，自律神経失調の特長の幾つかが見出される。 第一には135例中全身性愁訴が主訴上なるものが 多いことである。しかも体重減少の如き消耗性疾 患に扔いて，むし万特長的な症状を主訴とするも ののないこ上も興味浨い，第二に本症のうち最も 普遍的疗疾患しされるのは心朦神経症であるが， 私の結果ても循環性㮣訴を主訴之するものが多

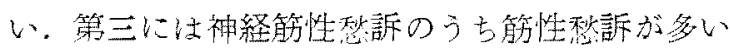
点であり，第四には殆じ全愁訴が主訴として平均 に訴えられている点も前迅の自律神経系の特長と 一致しているところである。

Clauser ${ }^{11)}$ 注自律神経失調症吕若年者に多く女 子に多いという，又自律神経が外界の焉化に強く 影響されることを考えれば，高温・高湿のわが国 の夏や天候の変化の注げしい等節の变り目に，失 調症が多心こ上もうなずけるであるう。良つて私 の成績でこれら 135 例が夏期・女性及び若年者に 多く分布していることは，や洁り二の效象が自律 神経失調者を多数含んでいることを暗示している ように考光られる。

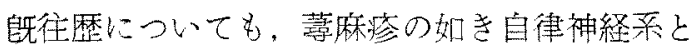
関係深い疾患の既往や肉体的及注季節的負荷苏誘 因となつているものが多く：二の点名本対象が自 律神経異常と濃厚な関係を有することを物語つて いるといえよう。

本症の他觉的所見は Scholz $z^{10)}$ の記載にもある
ように，極めて軽微な機能的なものが多い，私の 㸚象においてもその68.8\%は他覚的に無症状であ つた。沿療成續でも表 8 の如く，かなりの例が脚 気及びこれに類した疾惥と考えられがちであるに 拘らず，ビタミン $\mathrm{B}_{1}$ 济の治療成績恃決して留れ たものではなく，かえつて自律神経安定剷がすぐ れた效果を示している。

以上統計学的な観察においても，又臨床像の観 点加方もこれらの135例の中には自律袖経失調症 がかなり含まれていることが容易に考えられるで あろう。特に入院患者に扔いて原将患の経過中， これと全く平行せずに消長する多彩な症状が，原 疾患の治療によらず，自律神経系に直接向かうと ころの療法によつて消失したことは、これらの愁 訴が自律神経采の買常と密接な関連を有すること を示唆しているといえるう。これらの症状にも又， 全身性であり，多臟器に亘つているなど自律神経 失調症の特長をそなえている。

以上私の選んだ対象注他の如何なる器䁈的疾患 にも屬さず，しかもその臨床像を種々の観点から 眺めて，その多くが自律神経系の暴常を第一義的 な要素とする症例であることが推測された。しか しながらこれらの症例の多くが自律神経失調症で あると確診するには、これらの症例における自

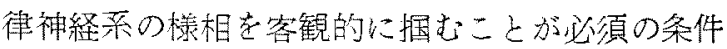
となることはもちろんである。今日多数の自律神 経機能梌查吕唱えられているが，いずれも一長一 短で，生体内にあつて複架な様相を呈する自律神 経系の調節不全を，適確に把握するに足るものが 見出されていない，元有能なる自律神経嘰能梌 查法を知るには，それぞれの模查法の洒值を制定 する確固たる指票が必要である。しかるに彷来こ の点に関しては極めて不明膫である。時には自律 触経系の薬理学的知見吕参若之なり，時には支配

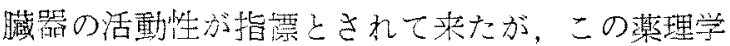
的知見にしろ，藏器の活動性にしろ，自律神経系 とのつながりは必ずしも確固たるものとなつては いない。

Eppinger und Hess 以来行なわれてきた交感 解経系，副变感神経系の分類にしても，その解剖 
学的もしくは楽理学的基礎は決して不安定なもの ではないに拘らず，なお臨床上にこれを応用する 場合に甠幾多の問題分提出されている現状であ

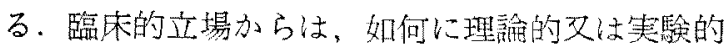
にその根底がしつかりしたものであつても、臨床 像を説明し得ず，又臨床的経過とも平行しない检 查法に多々を望むこ上仕できないであうう。この 意味においては臨床像の確立二そ自律神経䄼查法 批判の前提となるものである。

従つて私は，こ礼らの患者の種々の治療法のう ち，第一義的に自律陑経に向办う所の最当有能な るものを取り上げ，その治济前の自律神経機能と

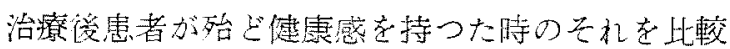
すること，及げ治療效果の上つたものと上ら好 のとの治療前の機能を比較することによつて，自 律神経機能検查法を批轪すると同時に，患者の自 律神経系の様相を知る方針をとつた。

有能なる治療法上して自律棟経安定绪老用いた 理由は，表 8 の治療成續又は表10の成續から明ら かである。私はこれらの成續に示されたところか

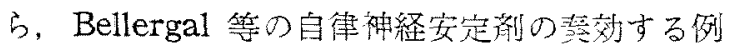
は, 第一義的に白律神経系の調整によつて治瘁せ しめられた症例であると考え。これらは自律神経 失調症であると仮定した。この仮定加らすれば安 定剂の琴効後俚自律神経正調者で女り，又安定郕 の無效な場合は，自律神経の正調な别の病因によ る病態であるか又はこれらの安定剂では治瘺し難 い量的に或は質的に異なる自律神経失調症である こととなる。

自律神経機能蚞查法としては，应るべく奏施の 簡單で被験者にも僨担の少ないものを選んだ。 呼吸时線の不整が自律神経失調に甚づくことは Mark $^{1)}$ が認めているが, White \& Hahn ${ }^{12)}$ や

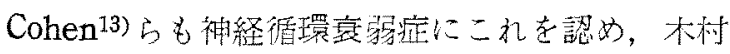
も心臓神経症の一つの客観的所圥にあげている。 又呼吸停止時間の短縮や過乎吸後に安静呼吸掼の 停止よりも，停止㭙間が短縮する現象が心蔵神経 症に諗められることは，斎藤の指摔する所であり，

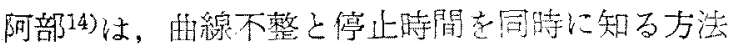

を提唱し, 脚気様状態の中で安定剂の有効な例 に，此線の不整及び停止時間の短縮のあることを 認如てる。今茾恃常相性便秘の自律神経異常を 知る手段として本法を応用し，陽性者の高率なる ことを報告した。私の成績でも健康人と安定用有 效者で活推計学的に有意の差をもつて有效者に高

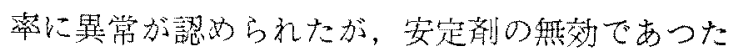
群と有効者群との間には著明な差はなく，又有効 群でも異常の少ないものがあり，個乃の症例を制 定する場合にはなお不充分な力法であることを知 つた，本法には自律神経機能乙密接な関係が知ら れているが，四吸機能に関与する自律神経系の様 相は極めて複雑であり，不明の点が多い，特に呼

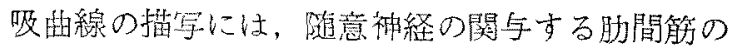
運動方多分に影暗を名つ，徒つてこのような自律 神経以外の影響が，繁効者群の陽性率を高めてい るものと想像される。

立位心電图でTの減高が自律神経失調者で著し いことは， Nordenfelt15) 以来多くの学者によつ て認められている，安部井忧康人，脚谷及び脚 気様状熊の中の bellergal 有效者を比較し, 前二 者に比し有效者でTII に有意の減高を認めてい る。私の成續でも有效群では $\mathrm{TII}=0.10 \pm 0.08$ $(\mathrm{mV})$ で, 安部井の健康人の平均 $\mathrm{TI}=0.04 \pm$ $0.05(\mathrm{mV})$ に比し減高度がはるかに大であつた が，無効者群との間には差を認めることができな かつた．特に減高0. $12 \mathrm{mV}$ 以上を異常值とした場 合には，有效群て名加なり正常檤の範围内にある ものが多く，促つて自律种経失調症を診断するに はなお不充分である，特心心臟性愁訴の多いも のでは他のものに此輘し高率に異常を示したこと

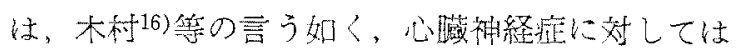
良い指標になることを示しているが，他の瀻器障 害像感前景に立つ自律神経失調症に対してあまり 偭值名ないことを物語つている。

Wenger-冲中法に関しては私の成續では全く治

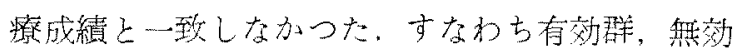
群において差を見出すことはできないばかりでな

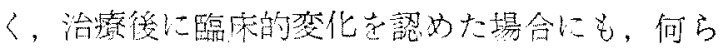


一定の変化を示さず，その大部分は健康人变動の 内部にあつた。本法に間しては最近多数の学者の 批判[7)方あり，理䄖的にも殆ど否定されている状 態で两る，従つて本法の成綨には多くを期待する ことはできないであるう。

Mecholyl 及び noradrenalin 試験は, Funkenstein らによつて Mecholyl-adrenalin 試騒と して提呾され，Gellhorn'昌 らによつて詳細な检 討が加えられ，Mecholy1 試験が交感神経中枢の 興盆性を反映したものであり，adrenalin 試験 が，副交感神経中枢の興鹪性を反映したものであ ること汃明らかにされた。 Nelson \& Gellhorn 法 adrenalin 0 代りに noradrenalin P.I. をるつて制定することを提媢した。 Mecholyl test の判定法には3法のあることは前遮し たが，Mecholyl 試験が血化降下に対する交感神 経中枢の反応性老示すものであるとすれば，血任 珀線の中で，上昇部分に最主意義がある。從つて この部分を最もよく反映した誀訪の制定がより合 理的である々考えられる。私の成續ではそれが 実証された。しかも安定用治療による臨床的経過

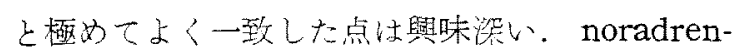
alin試験に関しては，予期した結果を得ることが

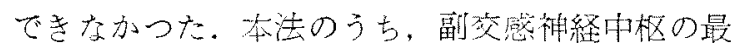

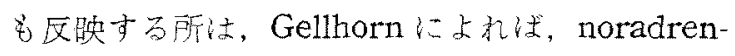
alin 静注に封ずる pulse slowing reflex にある。 住つて P.I. 值壮，本法莨制定す万最良の方法で あるとは考光難く，更に種々腫討を要するもの上 考えられる。

以上私注臨床像加自律神経失調症と思狈子 症例につき，種々の臨床成續加ら蚞討子ると共 に，各種の自律神経機能检查法により検討を加え

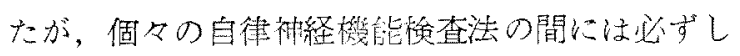
も一致した成績を得ることができなかつた。これ は、これらの松查法が, Wenger-冲中法老除いて はそれぞれ特定の落器系に片寄る傾向にある点 や，個ふの臓器の活動性のいくつかの指栖のう ち，必ずしも自律神経系に関係淡い指標をとつて いない点，又は負荷法であると安静時の力法であ
るとの差等，種々の要因によるものであり，むし ろ当然のことと考えられる。

又一方これらの検查法の成續と臨床成績との 間に見られた不一致は，私の立てた前述の仮説 に鿁りがあったことを証明することにもなり策 衫い、しかしなが方，二，三の检査法，特に Mecholyl test においては，この仮説をよく支持 する成續を示しており，従つてこのような不一致 は，むし乃個々の检查法に内在方る所の問題に上 るもの上考えねばならないであるう。

以上私は，臨床的に自律神経失調症を多数含ん でると予想して集めた症例の中に，加存り多数 の自律神経失調症が混在したことを知つた。すな わち，Mecholyl 試験の成績で, 63例中，有效群で は2例を除いた27例，無效群では34例中 S及び $\mathrm{P}$ 走した7例，合計34例 $(54.0 \%$ ) 任自律神経失 調症であると考充られる。残余の症例怯内科学的 な一般踟床㛟查成績のみでは区別し得なかつた症 例であり，精神神経症や内分必障害の面加らも詳 細に悛討すべき症例と考えられ、この点に関して は將来の研究にまちたい。

\section{結論}

1)種々の自律神経失調性愁訴を有し，諸種の 内科学的唡查法によつてもなお診断の不確実な症 例 135 例の臨床像を観察し，二れらの患者の主訴 が全身性愁挀や神経筋性・钼環性・胃晹性愁訴に 亘つて広範な分有意示す点，季節的因子に影響さ れている点, 女性及び若年者に多い点, 各種の自律

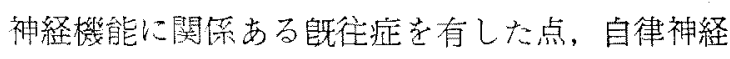
安定剂の素效率の高かつた点等からここの自 律神経失調症が高等に存在するものと想像した。

2）二のような患者の安定剂による治療效果を しらへ、これと各種自律神経機能积査法を比較し 次の結杲を得た。

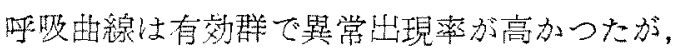
無效者で办なりの異常率省示した。

立位下減高では有效群は健康人上り減高度が大 であつたが，無効群との間には殆ど差を認めなか つた。立位T減高は循環性愁訴の強いものでは異 
裳培が哥かつた。

Wenger-冲中注及び noradrenalin 試䮖では, 有效群，無效群で差はなく，又治療後の成縝でも 一定の関係はなかつた。

Mecholyl 試歌て仗，諏訪法による判定法が最 当優つていて，安定剂有效群には治療前 $\mathrm{S}$ 型又は

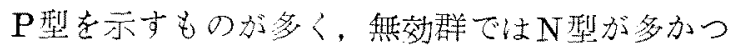
た。治療後では，有效例はNに推移寸るものが 多く，無效例ではN加らP疗はSになるものがあ り，治撚前S㕛は $\mathrm{P}$ 示したものは治療得も不变 であつた。

3）以上の臨床的成續上梌㚗成續加ら，自律神 経失調症を多数含んでいると予想された症例の中 の半数以上 (Mecholyl test では54\%) 洁自律神 経失調症であることを知つた。

（本論交の要旨は第57回日本精神神経学会総会及び 第1回日本精神身体学会総会に抬いて発表しだ。)

\section{文献}

1) Mark, R.E.: Klin. u. Ther. d. Veg. Dyst. Springer, Wien. 1954⿺り引用。 -2) 阿部: 治旗 37,1169 (1955) : 39, 250, (1957)。 - -3) 阿部 他：日内会誌42，260 (1953)。43，683 (1954). 46，474 (1957)，一4）阿部他：栄摩食糧誌11，16 （1958），一5）安部井：日内会誌48，558（1959）。6) Gellhorn, E.: Autonom. Imbal. \& Hypothal. Univ. Minnes. Press, Minneapolis, (1957). -7) 沖中，他：鼠新医学 14,2833 (1959). 一8) 䯅訪：

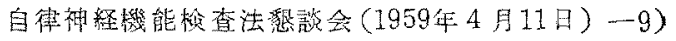
Wichmann, B.: Deut. Med. Wsch. 60, 1500 (1934). -10) Scholz, W.: Acta neuroveg, II, 329 (1951). -11) Clauser, G.: Lehrbuch d. inn. Med. (L. Heilmeyer) (1957). - 12) White, P.D. \& Hahn, R.G.: Am. J. Med. Sci., 177, 179 (1929). - 13) Cohen, M.E.: Med. Clin. North. Amer., 33, 1343 (1949), 一14) 阿部他: 治燎40，877 (1958). - 15) Nordenfelt, O.: Zschr. Kreisl. Forsch., 31， 761 (1939)。 - 16) 木村 他：治療39，462 (1957)。一-17) 藤标他：日本医事 新報1908, 3 (1960). 